\title{
EVALUATION OF THE RULE OF LAW AS A PREREQUISITE TO THE RIGHT TO DEVELOPMENT IN AFRICA
}

\author{
Simisola Akintoye* Ayobami Joshua ${ }^{* *}$
}

\section{INTRODUCTION}

The right to development appears to mean different things to many people. Judge Keba M'baye, a distinguished Senegalese Jurist, is credited with initiating the discourse on the concept of 'development' as a human right in a 1972 lecture held at the International Institute of Human Rights in Strasbourg, where he asserted that 'every man has a right to live and live better'.

To promote development and eventually the dignity of human beings, human rights and development have become two mutually related ideas that remain critical for any genuine, equitable global structuring or restructuring. ${ }^{2}$ The disproportionate pattern of the global economic system in the aspect of international economic development, particularly glaring on the African continent, has dominated several academic discussions since the period of decolonisation of the less developed countries of the world and still remains so till date. ${ }^{3}$

Although African continent has seen a measure of economic growth since the 1990s, yet most of this growth is unsustainable and tenuous. ${ }^{4}$

Simply put, Africa is far from a genuine economically developed region; and one of the significant reasons for this is the absence of true foundation for sustainable economic development, particularly the rule of law. ${ }^{5}$

\footnotetext{
Senior Lecturer in Law, De Montfort University Law School.

** Senior Lecturer in Law, Adekunle Ajasin University, Ondo State, Nigeria.

1 Judge Keba M'baye (Inaugural Address of the Third Teaching Session of the International Institute of Human Rights (July 3, 1972)) 5 Human Right Journals, 503, cited in Stephen Marks 'The Human Right to Development: Between Rhetoric and Reality’ (2004) 17 Harvard Human Rights Journal 137-168 at 138.

2 Salim Bashir Magashi, 'The Human Right to Development in Nigeria' (LLD thesis, Faculty of Law of Stellenbosch University 2006) 2.

3 Ibid.

4 Joseph M Isanga, 'Rule of Law and Africa Development' (2016) 42 North Carolina Journal of International Law and Commercial Regulation 57.

5 Ibid., 58.
} 
As noted by Currot:

the rule of law, by providing the framework for protecting private property and individual freedom, creates the stability and predictability in economic affairs necessary to promote entrepreneurship, saving and investment, and capital formation. It is nonsensical to expect ... economic development in Africa without addressing the institutional factors, such as the lack of rule of law, which are responsible for Africa's failure to develop in the first place. ${ }^{6}$

It logically follows that in the absence of the rule of law, the prospects of the application of the right to development as a human right to the many developmental challenges faced on the African continent are dim, when viewed against the background of the developmental crisis on the continent of Africa with its negative trickling down effect on the human worth and dignity of the overwhelming majority of the populace who are pitifully enmeshed in abject poverty, pauperisation, maternal mortality, diseases, hunger and malnutrition. This paper shall provide the reasons that undergird this perspective; it is obvious that the apparent economic development disparities among nations in the globalised world have produced severe socioeconomic consequences that challenge the universal concepts of equality, equity and fairness; concepts that are at the heart of both human rights and development discussions. ${ }^{7}$

\section{HUMAN RIGHTS, DEVELOPMENT, RIGHT TO DEVELOPMENT AND THE RULE OF LAW}

\section{Human Rights}

Human rights are those basic rights which all persons everywhere and at all times equally have by virtue of their status as human beings. ${ }^{8}$ Article 1 of the Universal Declaration on Human Rights states that all human beings are born free and equal in dignity and rights. ${ }^{9}$ It follows therefore that every human is entitled to enjoy

\footnotetext{
6 Nicholas Adam Currott, 'Foreign Aid, the Rule of Law and Economic Development in Africa' (2010) 11 UBOTSLJP 14.

7 Arjun Sengupta, 'The Human Right to Development' in Bard A Andreassen and Stephen P Marks (eds), Development as a Human Right: Legal, Political and Ethical Dimensions (Cambridge 2008) 13-15.

8 William Idowu, 'The Special Right, Theory within the Context of Human Rights: How Not to Reconstruct Sexual Equality’ (2012) 3 Human Rights Review 1.

9 United Nations, 'Universal Declaration of Human Rights' (United Nations, 1948)
} 
basic fundamental human rights that are universal in nature. ${ }^{10}$ There are diverse theories and theorisations about human rights. In intellectual discourses about the rule of law, the polemics usually swing between the natural law scholars and the legal positivists. ${ }^{11}$ To the legal positivist, human rights are products of law duly enacted by an authority empowered by law to do so; and thus commending people to obey or otherwise attract sanctions; in consequence, it is bereft of any moral or religious influence.

Conversely, the naturalists argue that human rights accrue to persons because they are human beings; they are 'inherent, fundamental and inalienable, universal, eternal and unalterable moral truths which attach to all human beings by virtue of their humanity. ${ }^{12}$ The latter view represents the most acceptable definition of human rights and is reflected in the international human rights conventions. As an instance, the office of the United Nations High Commissioner for Human Rights (OHCHR) defines human rights as:

Inherent to all human beings whatever over nationality, place of residence, sex, nationality or ethnic origin, colour, religion, language or any other status. We are all equally entitled to our human rights without discrimination. These rights are all interrelated, interdependent and indivisible. ${ }^{13}$

It has been said that the above definition captures the entire gamut of the theoretical, idealist and practical nature of human rights. ${ }^{14}$

The above descriptions suggest that human rights are essentially 'law based', in that a right should derive its status, relevance and enforceability from the law, even though it originated from somewhere else. This is in line with the argument

\footnotetext{
$<$ www.un.org/en/document /udhr/> accessed 6 October 2018.

10 Yemi Akinseye-George, Improving Judicial Protection of Human Rights in Nigeria (CSLJ, Abuja 2011) - cited in Olusegun, O and Ajigboye, O. "Realizing the Right to Development in Nigeria: An Examination of Legal Barriers and Challenges." [2015] Journal of Sustainable Development, Law and Policy 6 (1): 145-168.

11 See generally Margaret McDonald, 'Natural Rights' in Jeremy Waldron (ed), Theories of Rights (OUP 1984).

12 Ibid.

13 Office of the High Commissioner for Human Rights, 'What are Human Rights' (2015) https://www.ohchr.org/EN/AboutUs/Pages/FrequentlyAskedQuestions.aspx accessed on 12 December 2019.

14 Magashi (n 3) 19.
} 
of the positivists who postulate that to be enforceable, a right must be derived from a recognised source. ${ }^{15}$

\section{Development}

The term 'development' is a problematic concept. ${ }^{16}$ It has been one of the most ambiguous terms in intellectual discourses and it continues to generate controversies among scholars in related disciplines. In general terms, it is multidimensional, and could be viewed from political, economic and social angles. ${ }^{17}$ Development has been conceptualised as a multidimensional process, involving major changes in social structures, popular attitudes and national institutions, as well as the acceleration of economic growth, the reduction of inequality and the eradication of absolute poverty. ${ }^{18}$ Rodney, however, sees beyond people's perception of development, and conceived development in its economic, political and social terms. In his view, development requires that emphasis be laid on both 'increase in output and changes in the technical and institutional framework by which it is produced'. ${ }^{19}$ Put differently, development is basically about the process of change which lies around the different facets of life. ${ }^{20}$

Amartya Sen sees development in terms of both physical and psychological realities. ${ }^{21}$ The physical reality of development could be created in the existence of visible and concrete edifice like roads, hospitals, schools and factories among others.

Psychological reality consists in the capability of the citizens to enjoy the utility of physical development. ${ }^{22}$

15 Most human rights originated from morality and religion. However, they only become recognised and enforceable when they gain a legal endorsement. A good example is the incorporation of human rights in the Universal Declaration of Human Rights (UDHR) which was adopted on 10th December 1948. Perhaps without the declaration, modern societies would have been denuded of human rights.

16 Samson Ayobami Joshua, 'The Relevance of the Rule of Law to Good Governance and Development in Nigeria' (PhD thesis, Faculty of Law Obafemi Awolowo University 2017) 39 .

17 Ibid.

18 Michael Paul Todaro, Economic Development in the Third World (4th edn, Longman 1989) 23.

19 Walter Rodney, How Europe Underdeveloped Africa (Bogle-L'Ourverture 1972) 47.

20 Ibid.

21 Amartya Sen, Development as Freedom (OUP 1999).

22 Ibid. 
The popular thinking in the modern world is to conceive development in terms of economic growth of a country, and the Gross Domestic Product (GDP) is often used as the parameter to measure it. For example, the United Nations Development Programme (UNDP) in one of its Human Development Report (HDR) suggests that development is an end, while economic growth is the means to such end. ${ }^{23}$

Furthermore, the World Bank perceives 'development' as an entire range of changes in a particular society or social entity. It considers the test of development, mainly, to be the needs to improve quality of life, provide better education, create higher standards of life and nutrition, reduce poverty, promote cleaner environment, guarantee equality of opportunities and sustain individual freedom and richer cultural life. $^{24}$

Importantly, the United Nations Declaration of Right to Development (UNDRD) in its preamble sees development as a comprehensive process involving the economic, social, cultural and political processes; with the objective of sustainable improving people's well-being, based on their meaningful participation in the development process. ${ }^{25}$

\section{Right to Development}

Generally, the International Bill of Rights comprising the 1948 Universal Declaration of Human Right (UDHR), the International Covenant on Civil and Political Rights (ICCPR) and the International Covenant on Economic, Social and Cultural Rights (ICESCR), both from 1967, are acknowledged as precursors to the Right to Development (RTD). ${ }^{26}$ Although none of the earlier mentioned international instruments expressly mentions the RTD, their provisions have implicitly ${ }^{27}$ promulgated the RTD into existence. A good example is Article 22 of the UDHR which provides for the rights of every individual in the society to social security and realisation of his economic, social and cultural rights, which are deemed indispensable for their dignity and free development of his personality. ${ }^{28}$ Invariably, RTD

${ }^{23}$ UNDP HDR (1996).

${ }^{24}$ Quoted in Professor Bolaji Owasanoye, 'Rule of Law and National Development' in Epiphany Azinge and Bolaji Owasanoye (eds), Rule of Law and Good Governance (NIALS, 1999) 309.

${ }_{25}$ Magashi (n 3) 31.

26 Olusegun and Oyeniyi (n 11) 148.

27 Olajumoke O Oduwole, 'International Law and the Right to Development: A Pragmatic Approach for Africa' (Inaugural Lecture as Professor to the Prince Clause Chair in Development and Equity 2013/2015, The Hague, May 2014).

${ }^{28}$ See Article 22, UDHR <www.ohcr.org/EN/UDHR/Documents/UDHR_Translation/ eng.pdf/> Accessed 6 October 2018. 
has both external and internal dimension. The external dimension addresses inequality of the global political economy reflected in great inequities. Thus, this aspect of the right engages the responsibilities of states internationally when acting individually or collectively. The internal dimension of the right focuses on the obligations of every state to initiate domestic policies that promote the realisation of fundamental rights of all its citizens.

Margot Salomon ${ }^{29}$ has observed that the RTD derives its 'intellectual origins and legal claims' jointly from Article 28 and Articles 55 and 56 of the United Nations Charter. Some other treaties with development components include the International Convention on the Elimination of all Forms of Racial Discrimination (ICERD) ${ }^{30}$ Convention for the Prevention and Punishment for the Crime of Genocide (CPPCG) ${ }^{31}$ and the International Convention on the Suppression and Punishment of the Crime of Apartheid (SPCA), ${ }^{32}$ among others.

Originally perceived as a 'third generation' or 'solidarity right'33 the RTD was explicitly established by Article 1(1) of the UNDRD which states:

The Right to Development is an inalienable human right by virtue of which every human person and all people are entitled to participate in, contribute to and enjoy economic, social, cultural and political development, in which all human rights and fundamental freedoms can be fully realized. ${ }^{34}$

Furthermore, Articles 2(3) and 3(3) impose a duty on the states to design appropriate national development policies and to cooperate with each other in

${ }^{29}$ Margot E Salomon, Global Responsibility for Human Rights: World Poverty and the Development of International Law (OUP 2007).

${ }^{30}$ Adopted and opened for signature and ratification by General Assembly Resolution 2106 (XX) of 21 December 1965 entry into force on 4th January 1969. https://www.ohchr.org/en/professionalinterest/pages/cerd.aspx

31 Adopted by the General Assembly of the United Nations on December, 1948.

32 Adopted by the General Assembly of the United Nations on 30 November, 1973.

${ }^{33}$ Stephen Marks, 'The Human Right to Development: Between Rhetoric and Reality' (2004) 17 Harvard Human Rights Journal 137. In the 1970s and 1980s the RTD was introduced as one of several rights belonging to a third 'generation' of human rights. The first 'generation' consisted of Civil and Political rights conceived of as freedom from state abuse. The second 'generation' consisted of economic, social and cultural rights claims made against exploiters and oppressors; while the third 'generation' consisted of solidarity rights belonging to peoples and covering global concerns such as development, environment, humanitarian assistance, peace, communication and common heritage.

${ }^{34}$ United Nations Charter < www.un.org/en/documents>/ Accessed 6 October 2018. 


\section{THE DENNING LAW JOURNAL}

ensuring development and eliminating obstacles to development respectively. ${ }^{35}$ It is now commonly acknowledged that RTD alludes to both an individual and a collective right. ${ }^{36}$ Besides, the holders of the collective right are the people, to whom are owed obligations by the national government and international cooperation of governments to translate this right to a concrete reality for the people to enjoy. ${ }^{37}$

\section{Rule of Law}

Because of its significance, the concept of the rule of law has attracted a great deal of attention from scholars down the countries. ${ }^{38}$ The phrase 'rule of law' emerged as a theoretical concept formulated and debated by philosophers and legal theorists, and at the same time, it is a legal concept used by lawyers and judges. ${ }^{39}$ Its meaning is informed by both moral and legal theorists who investigated the abstract moral and political goals contained in the concept. ${ }^{40}$ Accordingly, the rule of law is not simply 'a set of mechanical rules to be followed; it is rather a set of loose, vague and indeterminate principles; which require interpretation in the light of the values which it is designed to realize. ${ }^{41}$

Because of its amenability to varying definitions and interpretations by philosophers and legal theorists, the literature on the rule of law is diverse and extensive. ${ }^{42}$ Brian Tamanaha has stated that the rule of law means that government officials and citizens are bound by, and therefore should abide by law. ${ }^{43}$

35 Ibid.

36 Oduwole (n 28) 5.

37 Ibid.

38 Randall Peerenboom, 'The Future of Rule of Law: Challenges and Prospects for the Field' (2009) 1 Hague Journal on the Rule of Law 7.

39 Ibid.

40 Ibid. [9], in his article titled: 'The Future of the Rule of Law: Challenges and Prospects for the Field', R Peerenboom explains that as the field has expanded, so have the definitions of the rule of law expanded. He stated that many definitions, in circular fashion, have been engrafted to the rule of law, in view of the objectives which it is meant to achieve, such as the protection of property rights, low crime rates and also democracy and political rights see also Francis Fukuyama, 'Transitions to the Rule of Law' (2010) 2(1) Journal of Democracy, 33-44; Adriaan Bedner, 'An Elementary Approach to the Rule of Law' (2010) 2 Hague Journal of the Rule of Law, 48-74.

${ }^{41}$ Funmilola Tolulope Abioye, 'Rule of Law in English Speaking African Countries: The Case of Nigeria and South Africa' (PhD thesis, Faculty of Law University of Pretoria 2011) 160-161.

42 Lon L Fuller, The Morality of Law (Yale University Press 1964), 41.

43 Brian Z Tamanaha, 'The History and Elements of the Rule of Law' (2012) 2 Singapore 
As stated earlier, the rule of law has remained a dynamic concept and the tenets encapsulated in the concept are limitless; ${ }^{44}$ as such, it embraces, in a narrower sense, terms such as due process, procedural justice and legal formality.

In accordance with the foregoing context, Dennis Lloyd highlighted the basic tenets of the rule of law to include the following: ${ }^{45}$

\section{(a) Independence of the judiciary}

Independence of the judiciary is synonymous with freedom from interference or pressure from the executive and legislative arms of government, along with friends, relations and peers. An independent and impartial judiciary is basic to the promotion of the rule of law; in that, it is the judiciary that has the responsibility of ensuring that both the government and the governed act in accordance with the laws. Judicial independence finds justification in the requirement of the separation of powers and the promotion of the rule of law. ${ }^{46}$

\section{(b) Speedy trial of accused persons}

The issue of speedy trial of persons accused of criminal offence is central to the concept of rule of law. The axiom 'justice delayed is justice denied' is quite valid. Delay in criminal trial would fetter the freedom of the accused unnecessarily. Besides, delay defeats the purpose of justice as time, resources, and opportunities are needlessly wasted. It amounts to a loss, not only to the society, but to the accused and the complainant/victim.

\section{(c) Judicial review}

Another significant tenet of the rule of law is the principle of judicial review. It implies that there exists adequate judicial control over executive and legislative actions. In practice, it means no member of the executive arm of government

\footnotetext{
Journal of Legal Studies, 232-233.

44 Professor Francis Chijioke Nwoke and Professor Dakas CJ Dakas, 'The Rule of Law as a Cornerstone of Democracy and Good Governance' (Proceedings of the $39^{\text {th }}$ Annual Conference of NALT 2003) 80.

45 Lloyd Dennis, The Idea of Law (Penguin Books 1964) 161-164.

46 David Pollard, Neil Parpworth and David Hughes, Constitutional and Administrative Law (4th edn, OUP 2007).
} 


\section{THE DENNING LAW JOURNAL}

shall exercise his executive function where there is no legal foundation for such act; whenever he does, the court has the power to nullify such act. In the same vein, the legislature shall not pass any law which is ultra vires its lawful powers. Were the legislature to offend, the court will strike down the offending legislation. ${ }^{47}$

\section{(d) Adequate legal assistance for the indigent}

It is also important that adequate assistance be given by the state to indigent citizens, who are accused of crime but are too poor to afford the cost of getting a good defense counsel. The tenet of equality of all persons before the law can only be well served if this safeguard exists.

\section{(e) Freedom and independence of advocates}

Rule of Law thrives better in a society where those charged with the duty of advocacy enjoy freedom and independence. Today, the persons, who by training and experience, are charged with the duty of advocacy are lawyers; they occupy an eminent position in determining, in every society, the fate of the rule of law. Without a strong, virile, vibrant, independent, respected, fearless and research-oriented bar, the rule of law can hardly thrive. ${ }^{48}$

\section{(f) The principle of presumption of innocence}

Another safeguard of the rule of law is the principle that every person accused of committing an offence shall be presumed innocent until he is proven guilty. Furthermore, the principle states that no person shall be guilty of an offence which is not specifically laid down in some law established prior to the date the alleged offence was committed. ${ }^{49}$

This expansive view of the rule of law has been adopted by most modern countries, particularly constitutional democracies, and the tenets are carefully enshrined in their various constitutions.

47 Brian Z Tamanaha, On the Rule of Law (Cambridge University Press 2004).

48 Mehr Chand Mahajan, Looking Back: The Autobiography of Mehr Chand Mahajan, Former Chief Justice of India (Har-Anand Publication 1963).

49 This principle is expressly enshrined in the Constitutions of most common law countries. For example, see s 36 (5), (8) and (12) of the 1999 Constitution of the Federal Republic of Nigeria. 


\section{THE RELATIONSHIP BETWEEN HUMAN RIGHTS, DEVELOPMENT AND THE RULE OF LAW IN THE CONTEXT OF RIGHTS-BASED APPROACH TO DEVELOPMENT}

\section{Human Rights and Development}

Experience has shown that no development regardless of how well designed and conceptualised can flourish without same form of legal prescriptions. ${ }^{50}$ Arguably, law and development are two mutually inclusive concepts. ${ }^{51}$ It is in recognition of this fact that United Nations Declaration of Right of Development (UNDRD) defines development as a human right. ${ }^{52}$ It has been stated earlier in this study that human right are those basic rights which all persons everywhere and at all times equally have by virtue of their status as human beings; it follows therefore that every human is entitled to enjoy basic fundamental human rights that are universal in nature. When viewed from this angle, it is logical to conclude that the right to development considers not only the marriage of human rights and development but also that development is in itself a human right. ${ }^{53}$

It is in this regard that the Millennium Development Goals (MDGs), the New Partnership for Africa's Development (NEPAD) initiatives as well as the renewed Sustainable Development Goals (SDGs) initiatives all have human rights undertones.

\section{Rule of Law and Development}

It has been argued that law can only function as a tool of development if it functions as it ought to, by imposing meaningful restraints on government actors and in limiting arbitrary state action; ${ }^{54}$ obviously the relationship between rule of law and (economic) development cannot be overemphasised. Seth W Norton has observed that property rights are necessary for growth. ${ }^{55} \mathrm{He}$ further examines empirical research that demonstrates that improved specified property rights

\footnotetext{
50 Magashi (n 3) 32.

51 Mamman Lawan, 'Law and Development in Nigeria: A Need for Activism' (2011) 55 JAL, 59-85.

52 Article 1 UNDRD.

53 Magashi (n 3) 33.

54 Randall Peerenboom, China's Long March toward Rule of Law (Cambridge University Press 2002).

55 Seth W Norton, 'Poverty, Property Rights and Human Well-Being: A Cross National Study’ (1998) 8 CATOJ 233.
} 
indicate higher levels of human development ${ }^{56}$ and that there is compelling proof that enhanced property rights greatly reduce the degradation of the world's poorest people; whereas weak property rights increase the degradation of poor people. ${ }^{57}$

In the same vein, Tamanaha posited that certainty, predictability and security play a key role in (economic) development. ${ }^{58}$

The relevant question here is will African countries (the focus of this study) achieve development if they adhere to the rule of law?

\section{RIGHT-BASED APPROACH TO DEVELOPMENT AGENDA}

The milestones in the evolution of the universal right to Development and later rights-based development are well documented in the literature, and there is no need to dwell extensively on that in this study.

The Right to Development (RTD) was explicitly established by Article 1(1) of the United Nations Declaration of Right to Development (UNDRD), which guarantees, among other things, that Right to Development is an inalienable right of every human person. Although it is now commonly acknowledged that this right refers to both an individual and a collective right, and that the collective right is vested in the people with a corresponding obligation resting on national governments, as well as a duty of international cooperation among states; yet right from the commencement of the RTD, there had arisen, between the developing and developed countries of the world, an argument about the holder of the right conferred by the RTD and those obliged to carry out the duty created by the right. The developing countries have taken the position that they were the right holders while the developed countries were the duty bearers (that is obliged

56 Ibid. [234].
57 Ibid.

58 Brian Tamanaha, A Concise Guide to the Rule of Law (St. Johns Legal Studies 2007). Tamanaha stated the above three prerequisite features of law that satisfies the demands of the concept of rule of law. He further argues that one function of the rule of law is to impose legal restraints on government (i) by requiring compliance with existing law, and (ii) by imposing legal limits on law-making power. This thesis finds supports in Joseph Raz 'The Rule of Law and its Virtue', (1977) 93 L.Q. REV, 198-201 where Raz identifies eight principles of the rule of law; viz (i) laws should be prospective, open and clear; (ii) laws should be relatively stable; (iii) the making of particular laws (legal orders) should be guided by open, clear, general rules; (iv) the independence of the judiciary must be guaranteed; (v) the principles of natural justice must be observed; (vi) courts should have review powers over the implementation of the principles of the rule of law in respect of administrative action and legislation; (vii) courts should be easily accessible; and (viii) the discretion of law enforcement agencies should not be allowed to pervert the law. 
to perform the duty created by the RTD in favour of the developing countries). In effect, developed countries have largely continued to refuse interpretations of the UNDRTD (that legally require them to give aid to particular developing countries, while developing countries continue to demand for more aid and concessions, a fairer international trade climate, access to technology and debt relief from developed countries on the ground that they (i.e. developing countries) face daunting development problems as well as potent threat of marginalisation in the globalisation era. At this point, it is needful to consider the nature and content of RTD.

\section{The Right to Development}

The right to development means that development is, itself, a human right and thus it prescribes the manner by which development can be viewed from the human rights perspective. The content of the right to development includes participation, international co-operation, self-determination, good governance, and equality of opportunity, among others..$^{59}$

To start with, the concept of participation suggests that individuals, groups and peoples should get involved in development activities, thereby making it possible for them to have the right to decide collectively and elect their own representative organisations. ${ }^{60}$ It is also important that they have control over those fundamental choices on issues affecting them and engage in all those mechanisms related to their welfare. ${ }^{61}$ As such, every form of inequality or discrimination on the grounds of sex, ethnicity, disability, religion and every other kind that could negatively impinge on the enjoyment of their human rights should be rejected. It remains to be seen whether this is the reality in the international community of states, particularly in less developed countries (including African countries).

Moving on to international co-operation, the United Nations by virtue of its Charter acknowledges the duty of international co-operation among States. In that context, international community of States and multinational bodies are required to co-operate to promote and enforce the human rights of all persons. ${ }^{62}$ The implication of this is that a state cannot act alone, that is, without giving

59 Magashi (n 4 ) 123.

60 Olusegun and Oyeniyi (n 12) 151.

61 Ibid.

62 Irene Hadiprayitno, 'Poverty, the Right to Development and International Human Rights Law' (2005) SSRN 2004 <http://ssrn.com/abstract=669227> accessed 28 March 2019. 
consideration to how its policies would have impact on other countries. The impact of the policies and practices of the developed countries on the less developed countries and vice versa, and the reaction of both necessitates international co-operation. ${ }^{63}$ A good illustration of this is foreign aid from developed countries to the needy less developed countries. The most important questions, however, is how well have such aids translated to better development for the recipient countries to foster genuine co-operation between the donor-developed countries and the developing countries?

The United Nations Declaration on the Rights to Development (UNDRD) maintains that development connotes the full realisation of the right of peoples to self-determination, and by virtue of that right, they can pursue their economic, social and cultural development without limitations. ${ }^{64}$ Self-determination in this sense is particularly significant to developing countries, (which largely include African countries), most of which are still economically and, to some extent, politically dependent on the developed countries, some of which once colonised them.

Governance connotes the traditional processes and institutions by which a given country exercises power. This embraces the means by which governments are chosen and replaced, the ability of the government to initiate and effectively execute policies and the measure of respect the citizens and the government have for the institutions established to actualise economic and social relations. ${ }^{65}$ According to its 1997 Yearly Report, the United Nations Development Program (UNDP) acknowledges Participation, Transparency, Responsiveness, Consensus Orientation, Equity, Effectiveness and Efficiency, Accountability and Strategic Vision as core characteristics of good governance. All these characteristics are given significant attention by the UN in the context of institutional reforms and other international agencies; against the background of the strategic relevance of good governance to the actualisation of right to development.

Lastly, the UNDRD affirms equality of all its beneficiaries by emphasising that development policy should be geared towards improving the well-being of the entire population and of all persons. ${ }^{66}$ Besides, States are enjoined to respect and promote the rights of all citizens regardless of race, sex, language or religion. ${ }^{67}$

63 Ibid.

64 Article 1(2) UNDRD.

65 Olusegun and Oyeniyi (n 12) 153.

66 Article 2(3) UNDRD.

67 Article 6(1). 
This implies that every person should have access to education, health care and employment on equal terms.

All the foregoing laudable provisions are at the core of the content of RTD; though laudable as they are, it is debatable whether their actualisation in concrete terms has been achieved in most nations of the world, especially, in the context of this paper, in African countries.

\section{Right to Development under International Law}

The right to development is a synthesis of existing rights. To this end, the twin covenants (the CCPR and the CESCR) constitute important sources of the right since in substance and spirit, they were drawn, from the UDHR. ${ }^{68}$ This is even more so considering that two vital components of the right to development, which are self-determination and international co-operation, are both recognised under these covenants. ${ }^{69}$ Additionally, the twin covenants contain specific rights that have direct positive implications on the right to development as an umbrella right. For example, the ICESCR recognises the right of everyone to work ${ }^{70}$ to social security, ${ }^{71}$ to cultural life, ${ }^{72}$ and to education which must be free and compulsory at least at the primary level and accessible at higher levels. ${ }^{73}$ Similarly provision of adequate standard of living, adequate food, clothing, housing, continuous improvement of living conditions of persons are recognised under this instrument. ${ }^{74}$ The ICESCR even goes ahead to recognise that everyone must be free from hunger. ${ }^{75}$ With regard to the right to health, Article 12 (1) of the ICESCR provides the right of everyone to the enjoyment of the highest

${ }^{68}$ The UNDRD Preamble 4 Provides: 'Recalling the provision of the International Covenant on Economic, Social and Cultural Rights and of the International Covenant on Civil and political Rights'.

${ }^{69}$ See Common Art 1 ICCPR and ICESCR; see also *UNDRD Preamble 6 which Provides: 'Recalling the right of peoples to self-determination, by virtue of which they have the right freely to determine their political status and to pursue their economic, social and cultural development'. At present 167 States have ratified both on 29 July 1993. <https:// treaties.un.org/Pages/ViewDetails.aspx?src =TREATY\&mtdysg-no=iv-4\&Chapter=4\&lang=en> accessed 28 September 2018.

${ }^{70}$ ICESCR Art 6.

${ }^{71}$ ICESCR Art 9.

72 ICESCR Art 15(1)(a).

73 ICESCR Art 13.

${ }^{74}$ ICESCR Art 11(1).

75 ICESCR Art 11(2). 
attainable standard of physical and mental health. To achieve this, states must take charge by ensuring the reduction of stillbirth and infant mortality rate as well as ensuring the healthy development of child. ${ }^{76}$ States must also ensure that all aspects of hygiene and the environment are improved, in addition to putting genuine efforts in the 'prevention, treatment and control of epidemic, endemic, occupational and other diseases' as well as in the creation of conditions which would assure medical services to all and medical attention in the event of sickness. $^{77}$

The right to development as a concept only came into existence at the UN level in 1986 with the adoption of the UNDRD. ${ }^{78}$ The UN mandated the High Commissioner for Human Rights to acknowledge the necessity of promoting a balanced and sustainable development for all peoples and also ensure the actualisation of the right to development, as established in the Declaration on the Right to Development. ${ }^{79}$ The High Commissioner was further mandated to establish a branch to be responsible for and the promotion and protection of right to development. ${ }^{80}$ It should be noted that the UNDRD is not a unique document in the sense of containing completely new rights not previously covered. ${ }^{81}$ It more or less reproduced existing human rights and obligations contained in the twin covenants into a single document with the purpose of harmonising them and pursuing them together. Its uniqueness lies in its articulation of developmentrelated rights and, where necessary, expanding these rights ${ }^{82}$ Like the instruments highlighted earlier, the UNDRD emphasises the need for international co-operation as a universal remedy for its achievement ${ }^{83}$ It is arguably one of the few known international instruments that defines human rights as an entitlement of both individuals and peoples at the same time. ${ }^{84}$ Human rights are largely conceived as individual entitlement. ${ }^{85}$

\footnotetext{
76 ICESCR Art 12(2)(a).

77 ICESCR Art 12(c)(d).

78 UNDRD; see also Stephen Marks, 'The Rights to Development: Between Rhetoric and Reality’ (2004) 17 Harvard Human Rights Journal 137-138.

79 Ibid. [138].

80 Ibid. [139].

81 Bonny Ibhawoh, Human Rights in Africa (Cambridge University Press 2018).

82 Ibid. [33].

83 UNDRD Art 1(3).

84 UNDRD Art 1(1).

85 See text below.
} 


\section{Right to Development under the African Human Rights Regime}

Most African countries have shown willingness to commit to the right to development. This is gleaned from the affirmation of this right as a peoples' right in the African Charter on Human and Peoples' Rights (ACHPR) ${ }^{86}$ and their contemporaneous continuous commitment to development at regional, sub-regional and national level.

As a matter of fact, the ACHPR was the first enforceable document to contain the right to development thereby making the African continent to be the first in conceiving it. ${ }^{87}$ The ACHPR unambiguously provides that 'States shall have the duty, individually or collectively, to ensure the exercise of the right to development. ${ }^{88}$ Article 1 of the ACHPR necessitates the African Union (AU) member states to take steps to 'recognise the rights, duties and freedom enshrined in the charter and shall undertake to adopt legislative or other measures to give effect to them. ${ }^{89}$ The ACHPR is the most important African treaty on human rights. ${ }^{90}$ Generally, most African states provide for developmental rights, especially economic, social and cultural rights in the form of fundamental objectives and directive of state policy (FODPSP) ${ }^{91}$ However, Ethiopia, Malawi, Cameroon and Uganda have gone further and recognised the right. The challenge of non-express recognition of human rights, through fundamental objectives and directive principles of state policy, usually results in legal tension with respect to questions of supremacy between constitutions and international law at times even involving extant laws. ${ }^{92}$

Generally, the African human rights system is fully grounded in its articulation of the right to development as a human right. ${ }^{93}$

\footnotetext{
86 African (Banjul) Charter on Human and Peoples' Rights (adopted 27 June 1981 entered into force 21 October 1986) OAU Doc GAB/LEG/67/3 rev 5,21 ILM 58(1982) (ACHPR).

87 Magashi (n 4 ) 119.

88 Article 1 of ACHPR.

89 Ibid.

90 Magashi (n 4) 119.

91 For example, Constitution of the Federal Republic of Nigeria (1999) chapter II; Constitution of the Republic of Ghana 1992 chapter 006; and the Constitution of United Republic of Tanzania (1977) part I.

92 Magashi (n 4) 121.

93 Ibid.
} 


\section{EXTENT TO WHICH THE EFFECTIVE ENFORCEMENT OF THE RULE OF LAW IN AFRICA HAS ASSISTED THE HUMAN RIGHTS-BASED APPROACH TO DEVELOPMENT}

Individually, several African states have adopted new constitutions, some of them explicitly entrenching the rule of law as a core value in constitutional governance. ${ }^{94}$ These states have also constituted courts with the jurisdiction to conduct judicial review, thus ensuring a system of checks and balances to reign in executive overreach. ${ }^{95}$ Several African states provide in their constitutions for the rule of law. ${ }^{96}$ But, as on a continuum, there are varying approaches to the rule of law depending on the history and political context of each country.

\section{South Africa}

South Africa is a beacon of hope for the region with regard to how the rule of law can be instrumental to development. Even in South Africa however, issues have arisen with regard to the extent the executive is willing to embrace the concept of the rule of law. The South African Constitution provides that 'the Republic of South Africa is one, sovereign, democratic state founded on the following values ... Supremacy of the constitution and the rule of law. ${ }^{97}$ But while South African Courts have pronounced themselves on the scope of the rule of law, judges have not been as unanimous with regard to its meaning and scope. The notion of rule of law was at the heart of the decision in Masethia $v$ President of the Republic of South Africa. ${ }^{98}$ At issue was procedural fairness as a requirement of the rule of law. ${ }^{99}$ Reading for the majority, Justice Moseneke ruled that the requirement of procedural fairness had been met because the president's constitutional power to appoint the head of each of the intelligence services was concomitant with the power to dismiss. ${ }^{100}$ Therefore, Masethia's argument that the President was required to adhere to the audi alteram partem principle by affording him a hearing before deciding to dismiss him was without merit? ${ }^{101}$ The majority insisted that the exercise of executive power should not be constrained by a procedural

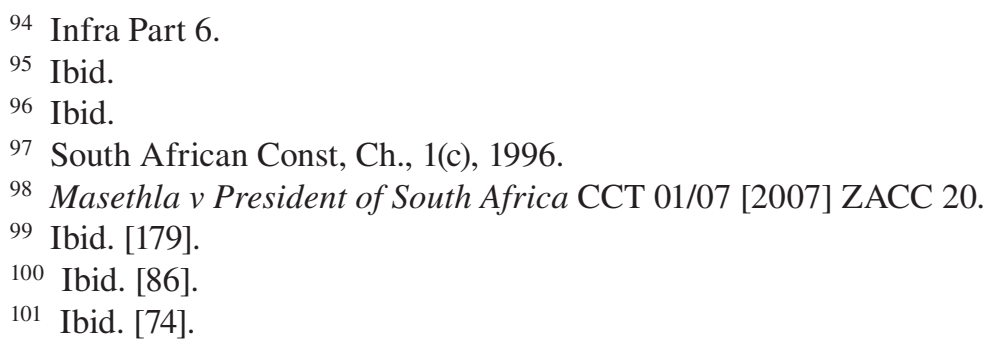


requirement. ${ }^{102}$ The court asserted that the only constitutional limit to the exercise of this power was the principle of rationality. ${ }^{103}$ Justice Ngcobo's dissent, however, differed slightly in analysis, with the Justice insisting that the rule of law requires legality or non-arbitrariness, that is, that public power be exercised in compliance with the law and within the boundaries set by the law. ${ }^{104}$

\section{Botswana}

Botswana exemplifies an African nation where, to a large extent, adherence to the rule of law has resulted in economic development.

For many years Botswana has been one of the world's fastest growing economies, with an average economic growth rate of $7.7 \%$. Without much foreign aid, and in the absence of a large state, Botswana has gone from being the third poorest nation of the world in 1965 to an upper middle-income nation today. ${ }^{105}$

Economist Scott Beaulier has asserted that the rule of law and comparatively free economic institutions are the major explanations for Botswana's greater success at economic development, in comparison to other African countries. ${ }^{106}$ Beaulier remarks that at independence, Botswana was bedevilled by typical problems of poor African countries such as famine, decayed infrastructure, illiteracy and poor health facilities among others. ${ }^{107}$ However, according to him, Botswana grew because its ruling elite made deliberate choices to increase economic freedom and avoided engaging in predatory practices. For some reason, Botswana's leaders were not interested in lining their own pockets. ${ }^{108}$ Respect for the rule of law allowed for entrepreneurship, economic development and social development. ${ }^{109}$

Botswana is exemplary in many respects. In order to provide for a system of checks and balances, critically important to the rule of law, the Constitution of Botswana implicitly provides for the separation of powers by dealing with each

\footnotetext{
102 Ibid. [78].

103 Ibid. See generally R Kruger, The South African Constitutional Court and the Rule of Law: The Masethla Judgment. A Cause for Concern? 13 Per. No.3, 2010 (discussing the questions and challenges arising out the Masethla decision in further depth).

104 Masethla (n 99) 242; 184.

105 Currott (n 8) 17.

106 Ibid.

107 Scott Beaulier and Laok Botswana, No Hands/Why Botswana Should Let the Country Free Itself (George Mason University Mercatus Centre, Working Paper No 53, 2005).

108 Ibid. [5].

109 Ibid. [11].
} 


\section{THE DENNING LAW JOURNAL}

organ of government in separate and distinct provisions. ${ }^{110}$ It is important to note that judges of Botswana's High Court and Court of Appeal are appointed on permanent, pensionable terms, and hold office until they reach compulsory retirement at the age of seventy. ${ }^{111}$ Additionally, several constitutional provisions refer to an 'independent and impartial' court or tribunal, ${ }^{112}$ and various acts of Parliament provide for independence and immunity of the judiciary. ${ }^{113}$

\section{Kenya}

Kenya has a history of a corrupt judicial system that was subjugated by repressive governments. Before the new Constitution of 2010, the law was unable to limit the President's power to unilaterally make decisions by not consulting the ministers or disregard the independence of the judiciary. ${ }^{114}$ The constitutional amendments of the 1960s, which were meant to increase the power of the President, ended up weakening the judiciary and had a negative consequence on the rule of law in Kenya. ${ }^{115}$ As a result, the public lost faith in their court's decisions in politically charged cases, such as Republic v Judicial Community of Inquiry into the Goldeberg Affair. ${ }^{116}$

110 Constitution of Botswana, ss 30-56 (executive); ss 57-94 (legislature); ss 95-107 (judiciary) (30 September 1966).

111 Ibid. [127 (8)].

112 Ibid. [10 (I)], [10 (9)], [14 (4) and [16 (2) (c)].

113 See, e.g., Customary Courts Act, 47 (granting indemnity to officers acting judicially for official acts done in good faith and while executing warrants and orders); High Court Act, c. 04:02, s 25(I) (stating that a judge shall not be sued in any court for any act done by him or ordered done by him); Penal Code Act, s 14(1986) (stating that a judicial officer is not criminally responsible for anything done or omitted in good faith in the exercise of his or her judicial functions).

114 Migai Akech, 'Abuse of Power and Corruption in Kenya: Will the New Constitution Enhance Government Accountability?' (2011) 18 Indiana Journal of Global Legal Studies341, 344.

115 Ibid. [376].

116 Republic v Judicial Comm'n of Inquiry into the Goldonberg Affair (2006) L.L.R. 1, 3-4 (H.C.K.). The outcome demonstrated that the court was an enabler of corruption because it quashed the findings of a commission into allegations of abuse and decided that George Saitoti, a Minister of Finance could not be prosecuted Ibid. [376]. The Court also held that, should criminal charge be brought against Saitoti, he would not be able to receive a fair trial and that because many years had passed Saitoti's constitutional right to a fair trial within a reasonable time would be violated. Ibid at 382 . In sum, the court 
Aware of this history, Kenya's new Constitution is awash with references to the rule of law, references that the courts have regularly emphasised as necessary for the economic and political development of Kenya. ${ }^{117}$ The Constitution of Kenya is premised on the recognition of "the aspirations of all Kenyans for a government based on the essential values of human rights, equality, freedom, democracy, social justice and the rule of law. ${ }^{118}$ The Constitution uniquely provides that '[e] very political party shall promote the objects and principles of this Constitution and the rule of law.'119

\section{Zimbabwe}

Zimbabwe most eloquently illustrates the thesis that the rule of law is an important prerequisite for genuine economic development. One reason for this is that potential investors are more interested in the prevalence of law and order, the absence of arbitrary regulation and the possibility of expropriation. The quantum of investment in countries not having the security provided by the Rule of Law is severely limited, reducing the likelihood of economic expansion. ${ }^{120}$ During Mugabe's rule, the decision to cast aside the rule of law to carry out much needed and justified land reform, made Zimbabwe's economy grow worse, ${ }^{121}$ as the judges opted for a formalistic understanding of the rule of law, ignoring the law's substantive justice. $^{122}$

reasoned that because Saitoti had already been tried in the legislature, it should amount to double jeopardy if he were to be tried in court of law. Ibid at 376-382.

117 Constitution (2010) (Kenya).

118 Ibid. [preamble].

119 Ibid. [91(l)(g)].

120 Currott (n 8) 14.

121 BBC, 'Robert Mugabe Admits Zimbabwe's Land Reform Flaws' (BBC, 27 February 2015) <http://www.bbc.com!news/world-africa-3>

122 'The main problem regarding land reform has been lack of resources to buy the land in accordance with the constitutional stipulations'. Michelo Hansungule, 'Who Owns Land in Zimbabwe? In Africa?' (2000) 7 International Journal On Minority and Group Rights 305, 336. Mugabe made it clear that he would not respect international law on compensation in the event he did not have the money, at 338. Texaco Overseas Petroleum Co. $v$ Libya [1978] 17 ILM 1 (standing for the proposition that under international law, there is no dispute that countries can expropriate private property, but they have to pay appropriate compensation). But to get around that by violating the rule of law, from the substantive point of view, only exacerbates the problem Hansungule [336]. Moreover, the Mugabe administration appears to have repeated the same errors committed during the colonial era by 'allocating land to government officials and party supporters'. 
The doctrine of separation of powers, which is essential to creating a system of checks and balances in the rule of law, is notably missing in Zimbabwe's Constitution. ${ }^{123}$ According to the Constitution, the legislature consists of the President and Parliament. ${ }^{124}$ Although the Constitution has a Declaration of Rights, which is directly enforceable before the Constitutional Court of Zimbabwe, ${ }^{125}$ most of the rights included have serious derogations attached to them, and the Supreme Court of Zimbabwe restrictively interpreted the scope of those derogations. ${ }^{126}$

\section{REALISATION OF THE RIGHT TO DEVELOPMENT IN AFRICA - THE PRE-EMINENT RESPONSIBILITY OF THE AFRICAN UNION (AU)}

\section{Right to Development}

The Right to Development finds full expression in the African Charter on Human and Peoples' Rights (ACHPR). This has also subsequently been advanced by the adoption of the UN Declaration on the Right to Development (DRD) (contained in the 1986 UN General Assembly Resolution 41/126). The right to development goes beyond economic or social development to include both independent right and the right that is intrinsically linked to the full enjoyment of a range of human rights with social, cultural, political and economic dimensions.

One of the key elements included is direct participation in development. This implies meaningful connection to resources and opportunities as well as to institutions and systems of social organisation and governance. It is not enough for people to be passive beneficiaries of welfare and social benefits or to vote in elections. Such participation is achieved through the exercise of civil and political rights which create discussion and debate, and in turn make room to influence policies. ${ }^{127}$ Another fundamental element included is sustainable development. Sustainable development is the ability of countries to critically engage with the economic, social and environmental impact of sustainability that focuses on meeting the developmental needs of the present without compromising the

\footnotetext{
123 See Constitution of Zimbabwe, s. 116 (May 9, 2013) (vesting legislative power in both the President and parliament).

124 Ibid.

125 Ibid.

126 Ibid. [5].

127 African Charter on Popular Participation in Development and Transformation, 1990.
} 
future. ${ }^{128}$ The promotion of peace and security and right to self-determination are also notable elements of development. Self-determination refers to a people's right to elect their government freely; to choose their own manner of pursuing social, economic and cultural development; and to have control over their resources and wealth.

Bearing in mind that the right to development seeks to remove the artificial distinction made between so-called first-generation (civil and political) and second-generation (social, economic and cultural) rights, it goes without saying that violation of any of these rights is tantamount to a violation of all the elements comprised thereof.

In recognition of the importance that the $\mathrm{AU}$ attaches to the enjoyment of all human rights, the AU Commission adopted a strategic plan which placed human rights at the core of its social development programmes and activities. One of the key roles of the AU's Department of Social Affairs is to provide the political leadership to harmonise and coordinate Africa's efforts in ensuring that noticeable improvements are made in the lives of all Africans. It does so within the context of the right to development, as embodied in the African Charter on Human and Peoples' Rights, the AU Constitutive Act and the Vision and Mission of the AU Commission. The Department of Social Affairs' programmes encompass numerous issues, including health and endemic diseases, migration, population, reproductive health and rights, culture, sport, social protection of vulnerable groups, gender equality, education and human resource development. Special attention is given to marginalised and disadvantaged groups and communities.

It is important to also draw inferences from a number of specific measures which have been taken by the AU Commission in addressing the social challenges at continental levels.

One of these is the 1999 Charter for Social Action which incorporates a variety of principles including respect for basic human rights, the basic needs and aspirations of the population, pursuit of the goals of social justice and equity and accessibility of social services to all. Among its strategies, the Charter calls for the formulation of national social policy and the incorporation of the social dimension at all level of planning, programming and implementation.

Secondly, there is the 2004 Ouagadougou Declaration and Plan of Action on Employment and Poverty Alleviation, ${ }^{129}$ which expresses concern about the sustainable livelihoods of the African population in general, and those of vulnerable groups in particular. The Declaration calls for equal opportunities for

\footnotetext{
128 United Nations Sustainable Development Agenda 2030.

129 Adopted at the Extraordinary Summit of Heads of State and Government in September 2004.
} 
all and commits its signatories to empowering the most vulnerable groups, including them in poverty alleviation programmes and policies, and ensuring their full participation in the implementation of these programmes.

Furthermore, in 2008, the African Union Social Policy Framework was published. ${ }^{130}$ This provides guidance to member states in the promotion of the rights and ensuring the welfare of marginalised and excluded groups, including orphans, other vulnerable children; the youth in general, people with disabilities, refugees and displaced people, families, the elderly and people living with HIV and AIDS. The development of the Policy Framework was informed by Africa's need to combine economic dynamism (including 'pro-poor' growth policies), social integration (societies that are inclusive, stable, just and based on the promotion and protection of all human rights, nondiscrimination, respect for diversity and participation of all peoples), and an active role for government in the provision of basic services at local and national level. In this context, it has been recognised that social policy should (a) promote equity and fairness among certain segments of society and certain regions within a country (otherwise it leads to social exclusion) by providing equitable access to rights and resources; (b) address the social tension between cultural identity and aspirations towards the freedoms promised by modernity; (c) reflect the true realities of Africa that bring together economic and social policies, thus recognising the interdependency between the two; and (d) promote a human development approach that puts people at the centre of development, by investing in people.

Based on the above, it is clear that development is not just about economic growth: it encompasses social advancement and the betterment of livelihoods.

Central to the right to development is social, economic and cultural rights. Whenever reference is made to the promotion and protection of human rights, there is an inclination to speak about civil and political rights only. In this regard, the yardstick for measuring the enjoyment of such rights has been the full and active participation of people in democratic processes such as elections, freedom of expression and the right to life. African countries have been hailed for increasing respect for human rights as more countries emerged through democratic transitions following elections through which people freely choose their governments. However, participation in elections should not be the only human rights indicator; rather, and more importantly, the indicator should be the full and equal enjoyment of social, economic and cultural rights.

Therefore, poverty can be seen as a violation of human rights, and its reduction will contribute to the full and equal enjoyment of all human rights.

130 AU Social Policy Framework for Africa 2008. 


\section{Right to Development and the Challenges Faced by Less Developed African Countries}

Over the years, the United Nations has made efforts to identify and remove obstacles to the realisation of the right to development. ${ }^{131}$ However, the realities of underdevelopment in less developed countries of the world run counter to these efforts. Development is curtailed by several indices, which constitute the obstacles of the Right to Development (RTD). Unfortunately, these obstacles affect the underdeveloped and developing countries more.

Some of these challenges are:

\section{Insufficient Foreign Aid}

In developing countries, foreign aid plays a large role in realising the right to development. In view of this, the United Nations held an International Conference on Financing for Development in Monterrey, Mexico in 2002 as a global response to the challenges of finance and development across the world, with particular focus on developing countries. The goal was to develop an inclusive economic system that eradicates poverty, while promoting sustainable development. ${ }^{132}$ However, the volume of external aid to developing countries has declined over the years. Aside from the overall level of assistance, there are shortcomings in the manner of its distribution as some countries are preferred over others for reasons such as political motivation, maintaining influence, strengthening their international comparative advantage and international competitive edge in respect of trade and investment. Also, some government of donor states, often suppress human rights considerations in aid or development negotiations. ${ }^{133}$

131 This is evident in Conventions, which contain provisions protecting key groups against discrimination. See, for example, Article 2, United Nations Convention on the Rights of the Child (CRC), Article 2, 7, 8, 11, 12 Convention on the Elimination of Discrimination against Women (CEDAW). International Convention on the Elimination of All Forms of Racial Discrimination, United Nations Convention on the Rights of Persons with Disabilities.

132 See the United Nations Report on International Conference on Financing for Development, Monterrey, Mexico, 18-22 March 2002. Available at http://archive.ipu.org/ splze/ffd08/monterrey.pdf Accessed 3 December 2019.

133 Dejo Olowu, Conceptualizing an Integrative Right-Based Approach to Human Development in Africa: Reflections on the Roles and Responsibilities of Non-State Actors (Copenhagen: Danish Institute for Human Rights 2005) 32. 


\section{Corruption}

A corrupt activity is that which violates the ethics of society or the ethics of one's office, position, profession or calling. ${ }^{134}$ Corruption, though a global problem, varies from one country to the other and is most evident in developing countries. ${ }^{135}$

The negative impact of corruption on development is no longer questioned. Corruption hinders economic development, reduces social services and diverts investments in infrastructure, institutions and social services. ${ }^{136}$ It has been described as immoral, unjust and repugnant to the ideals of humanity enshrined in the Universal Declaration of Human Rights; hence falls into the same category as torture, genocide and other crimes against humanity that rob humans of human dignity. ${ }^{137}$ This is so because the funds and resources that should be allocated for use in tangible projects that will promote the well-being of citizens are diverted into personal pockets. ${ }^{138}$ Various reasons could be attributed as factors promoting corruption in African countries; these includes greed, lack of transparency, inadequate strategic vision, few incentives for effective performance and weak monitoring mechanisms, among other; the effects of these are manifested in poverty of the masses, low civil service salaries and poor working conditions. ${ }^{139}$ All these have a telling effect on the realisation of right to development in Africa.

\section{Consequences of Globalisation}

Globalisation can be defined as a process whereby economic openness, economic interdependence and economic integration are increased between countries of the world. Its implication, therefore, is that every country, either developed or developing, would have access to every other country. ${ }^{140}$ Globalisation is responsible for

\footnotetext{
134 Osita Nnamani Ogbu, 'Combating Corruption in Nigeria: A Critical Appraisal of the Laws, Institutions and the Political Will' (2010) 14 ANNSICL 99, 102.

135 Victor Egwemi, 'Corruption and Corrupt Practices in Nigeria: An Agenda for Taming the Monster' (2012) 14 JSDA Journal of Sustainable Development in Africa 72.

136 UN Anti-Corruption Practice Note, February 2004.

137 Raj Kumar, Corruption and Human Rights in India: Perspectives on Transparency and Good Governance (OUP 2011) 34.

138 Obayelu, 'Effects of Corruption and Economic Reforms on Economic Growth and Development: Lessons from Nigeria' (UNECA, 2007) <www.uneca.org/sites/default/files/ page_attachments/abiodun_elijah-obayelu-o.pdf>accessed 28 March 2019.

139 Ibid.

140 Gbenga Lawal, 'Globalisation and Development: The Implications for the African
} 
the increasing gap between the rich and the poor and the unfair labour standards in the developing world. ${ }^{141}$ The uncomfortable truth about globalisation is that it made African countries a huge dumping ground for products exported to Africa from developed countries, and by extension discouraging industrialisation and technological development of African countries. The consequence of these is the inability of the developing African countries to compete on favourable terms with developed countries at the international market; thereby turning them into 'economic slaves' of the developed countries. Unfortunately, governments in African countries have contributed to this inequity by their irresponsible and heartless exploitation of their own citizens for personal gains. Under this circumstance, actualisation of the right to development remains a mirage.

\section{Weak Enforcement of Laws and Policies}

Laws are only effective when they are well implemented and enforced. According to DeGroff and Cargo, ${ }^{142}$ 'implementation is an iterative process in which ideas, expressed as policy, are transformed into behaviour, expressed as social action.' The social action transformed from the policy is aimed at making the society better and manifests as programmes, procedures, regulations or practices. In most less developed African countries, many laws are laid down without effective implementation, at the end of the day, the resources and efforts that have been expended in making such laws become a waste and the problem for which the law was intended to solve will persist.

\section{Poverty}

Poverty affects development negatively in several ways. It affects an individual's access to basic necessities of life such as housing, food and health care. It also propels people to engage in different forms of crime such as human trafficking, robbery, kidnapping, all of which negatively affect the development of countries. More funds will thus have to be injected into the criminal justice system instead of

Economy' (2006) 1(1) Humanity \& Social Sciences Journal 65.

${ }^{141}$ Elli Louka, International Environmental Law: Fairness, Effectiveness and World Order (Cambridge University Press 2006) 49.

${ }^{142}$ Amy DeGroff and Margaret Cargo, 'Policy Implementation: Implications for Evaluation' in JM Ottoson and P Hawe (eds), Knowledge Utilization, Diffusion, Implementation, Transfer, and Translation: Implications for Evaluation (New Directions for Evaluation 2009) 48. 
being spent on other important things. ${ }^{143}$ Poverty creates disparity in educational attainments as children of school age either drops out for lack of money on the part of their parents/guardians or could not even at all. Besides, poverty robs poor African countries of the most productive segments of their populace as lack of access to good health care, sanitary living environment and hygienic working conditions lead to many premature deaths, thereby denying the countries of quality manpower that could ensure their economic growth. This remains a potent obstacle to the actualisation of right to development.

\section{Lack of Respect for All Human Rights}

In order to achieve development, States must put the human rights of its citizens into consideration without any distinction as to race, sex, language or religion and such rights must be indivisible and interdependent. ${ }^{144}$ Thus, a certain category of rights should not be more important than others. Governments with sufficient resources may however lack the will to implement human rights institutions and policies if it does not see it as a priority. ${ }^{145}$ The failure to protect human rights constitutes an obstacle to development. ${ }^{146}$ Government should protect people from human rights violations such as apartheid, racism and racial discrimination, colonialism, aggression, foreign interference and threats of war. ${ }^{147}$

\section{Lack of Institutional Capacity}

Globally, institutions are often saddled with the responsibility of fostering development. However, strengthening institutional capacity remains a major challenge. This is largely due to the relationship and link that exists between the organisations and their host communities. Institutions tasked with providing services and products to their constituents across a wide spectrum of sectors often face daunting challenges as they struggle to perform in developing country environments which are undergoing or recovering from political, social and economic upheaval. ${ }^{148}$ These challenges and more such as bureaucratic cultures often affect

\footnotetext{
143 Attahiru Muhammadu Jega, Democracy, Good Governance and Development in Nigeria (Spectrum, 2007) 171.

144 Article 6(1) and 6(2) UNDRD.

145 Lanse Minkler and Shawna Sweeney, 'On the Indivisibility and Interdependence of Basic Rights Developing Countries’ (2011) 33 HRQ 351.

146 Article 6(2) UNDRD.

147 Article 5 UNDRD.

148 Human and Institutional Capacity Development Handbook: A USAID Model for
} 
the ability of any well-established organisation in the developed world to adapt and thrive in their new host community.

\section{RECOMMENDATIONS AND CONCLUSION}

\section{Recommendations}

While Africa is an important frontier in economic development, respect for the rule of law continues to lag in most African countries. The anti-Western rhetoric that dominated development strategies prior to the adoption of the Constitutive Act of the African Union has largely diminished, but it has not completely disappeared. The AU continues to emphasise respect for the principle of non-intervention in the internal affairs of member states, which has led the AU to adopt an uncritical stance towards some African states where the rule of law is largely disregarded.

For sustainable development, it is important for African countries to continue to develop institutions dedicated to good governance and the rule of law. In particular, it is important that judicial independence be assured. At the regional level it is crucial for human rights institutions, like the African Court of Human Rights and the African Court of Justice and Human Rights, to develop into robust and respectable oversight and enforcement institutions. However, this will not happen until the constituent legal instruments for these institutions are amended to ensure that African countries do not have a choice of whether or not to make a declaration accepting the jurisdiction of these institutions regarding individual petitions before them. Additionally, it is imperative that African countries find better mechanisms to assure compliance with court decisions.

As African countries forge business relationships with foreign countries, they must also ensure that the legal instruments embodying those relationships clearly indicate the human rights obligations of foreign businesses operating in Africa. These obligations are already spelled out in some African human rights instruments, making it a state obligation.

It is necessary to realise that legal solutions alone cannot work because legal and judicial solutions are highly dependent on the political climate. First, in order to improve the political environment, there is a need to focus on political leverage by more developed countries in Africa and elsewhere. The international community, especially the more democratic and developed parts of the world,

Sustainable Performance Improvement prepared by the Participant Training team in the Office of Education, Bureau for Economic Growth, Agriculture \& Trade, 10/2010 <http:// pdf.usaid.gov/pdf_docs/PNADT442.pdf> accessed 16 October 2018. 
could use their leverage in Africa to encourage greater respect for human rights and adherence to the rule of law. In far too many countries like Uganda, Ethiopia, Rwanda, Kenya, developed, democratic countries, such as the United States, condemn their actions and yet continue to work with ruling political regimes that pocket foreign development aid and maintain a repressive grip on power. Second, focusing on local civil society organisations will be imperative to promote change locally. Third, it is vital to recognise and highlight bold judicial decisions across Africa which shows there are judicial institutions willing to take on the establishment in order to promote the rule of law, respect for human rights and democracy. Fourth, and relatedly, it is important to highlight those African countries regarded as best-practices countries, these would be countries that have consistently promoted the rule of law, respect for human rights and democracy and have had development as a result.

\section{Conclusion}

An economically strong Africa can only mean great things for the international community as a whole. Nevertheless, in order to get there the individual African countries must realise the importance of development, the rule of law and human rights. Countries need to avoid making arrangements that perpetuate authoritarianism at the expense of sustainable development, and must avoid arrangements that could impede the much-needed developments in many ramifications. In many countries, judiciaries are not powerful enough to stand up to the executive in order to uphold the rule of law. Until that happens, many African countries cannot make the necessary breakthrough on the path to sustainable development. 